\title{
STRATEGY ANALYSIS OF FINANCING MANAGEMENT QUALITY TOWARD PERFORMANCE IMPROVEMENT OF ISLAMIC HIGHER EDUCATION IN LAMPUNG
}

\author{
Tulus Suryanto, Siti Patimah \\ Universitas Islam Negeri Raden Intan Lampung, Lampung, Indonesia \\ E-mail: tulus@radenintan.ac.id
}

\begin{abstract}
The purpose of this study was to determine the formulation of strategies for improving the quality of management performance at Islamic Higher Education in Lampung, knowing the planning process and implementation of strategies carried out by Islamic Higher Education in Lampung, knowing leadership and management behavior in meeting the expectations of Islamic University Stakeholders in Lampung and knowing the suitability of the quality of the management performance of the preferences of the Management Stakeholders and Staff of Islamic Universities in Lampung. Data collection techniques in this study used a questionnaire and data analysis techniques with a qualitative approach. The results showed that the two Universities in Lampung in the formulation of strategies for improving the quality of performance have not been systematic, changes in the strategic environment have not been followed by proactive steps; the process of implementing the strategy has not been carried out maximally in the allocation of available resources; based on strategic management, the two institutions are still influenced by bureaucratic culture and low adjustments to change; Islamic tertiary institutions in Lampung have negative or maximum gaps in the role of leadership.
\end{abstract}

Keywords: Finance; Financing Management; Performance; Islamic Higher Education

\section{INTRODUCTION}

Higher Education is an institution or institution that develops science and technology. The function of strategic tertiary institutions is to improve competitiveness, both the competitiveness of human resources and the nation's competitiveness. The global demand which is always changing rapidly and erratically Universities to always make changes towards the improvement of more developed and advanced and quality education. The meaning of global competition is the shift from a comparative advantage (competition for human resources) to a competitive advantage.

The reality of relevance in tertiary institutions is a gap or gap between the needs of the community and the world of work that cannot be anticipated and developed. This disparity in community needs and educational output can be identified through high unemployment. 2030 is predicted to be the peak of Indonesia's demographic change and will push Indonesia towards "Windows of Opportunity". However, the meaning of the Demographic Bonus itself is a condition that causes an increase in the population of productive age and will be able to influence economic growth due to the level of consumption and investment done high, so that the dependency number will decrease.

Based on the Central Statistics Agency, the August 2017 period experienced an increase in the number of workers obtained by 2.62 million people, while in August 2016 there were 125.44 million people. But on the other hand, the number of unemployed people in Indonesia until August 2017 was 10,000 people. Nevertheless, in terms of the unemployment rate percentage decreased in August 2016 amounted to $5.61 \%$ or 7.03 million people and in August 2017 it became $5.50 \%$ or 7.04 million people (Kusuma, 2017).

Issues of relevance and low quality of tertiary institutions have an impact on the low competitiveness of human resources and competition in tertiary institutions, besides, the lack of competencies following the desires of the industry is the reason for not accommodating graduates from tertiary institutions. The great difficulties faced by tertiary institutions to achieve standardized quality, especially in the areas of basic competence.

The decrease in the number of students going to PTS with medium and small scale is also a threat to IAI Agus Salim 
Metro and STAI An Nur Lampung. Universities with very few students. From 11 campuses, there are around $80 \%$ of students with $<100$ students per study program. Another thing experienced by higher education in Indonesia is when faced with quality problems. This issue is the motivation of various universities to work hard in improving quality so that they can compete and gain public trust and still exist.

Low human resources are another problem experienced by IAI Agus Salim Metro and STAI An Nur Lampung. The problem that is often faced is the delay of speed in development that occurs outside of other education. The steps that need to be taken are not only to change the curriculum so that it is related to the needs of the moment, as well as the concept of link and match launched by the Minister of Education and Culture, also cannot be interpreted narrowly.

An organization (higher education institutions in Indonesia) in dealing with the process of global change so as not to become a victim of these changes, the IAI Agus Salim Metro and STAI An Nur Lampung must be able to develop a proactive and interactive strategy. The role of critical human resources is expected to be able to combine routine activities and activities that require the development of human creativity by optimizing creativity, taste, and work while building a dynamic educational organization culture (RADe.Rozarie, 2017).

Reforming the internal organization and making significant changes to management and leadership are steps to address and overcome the above problems. The effectiveness of the management role alone is not enough, but also must be accompanied by leadership (Martono and Wijayanto, 2014). This is to keep the organization alive and developing and to create high value for its sustainable constituents. To answer the challenges, a strong leadership role is needed, especially in business competition that will emerge in terms of implementation or operation (Sumardjoko, 2010).

Based on the discussion above, the following formula is obtained: (1) How to formulate a strategy for improving the quality of management performance at IAI Agus Salim Metro and STAI An-Nur Lampung? (2) What is the process of planning and implementing the strategy carried out by IAI Agus Salim Metro and STAI An-Nur Lampung? (3) How do leadership and management behaviors meet the expectations of IAI Agus Salim Metro and An-Nur Lampung STAI stakeholders? (4) How is the quality of management performance following the management preferences of IAI Agus Salim Metro and STAI An-Nur Lampung?

Basically, Higher Education is a milieu that is driving the emergence of change in society. Whereas in general, the forming system of a community's intellectual formation.

According to the Law of the Republic of Indonesia Number 20 the Year 2003 Regarding National Education System, Article 20 paragraph 1 was stated as follows: "(a) The academy organizes vocational education in one branch or part of a particular science, technology, and/or art group; (b) Colleges provide academic and/or vocational education within the scope of a particular discipline of science and if they meet the requirements to be able to organize professional education; (c) The Institute organizes academic and/or vocational education in a group of scientific, technological, and/or artistic disciplines and if eligible meets professional education; (d) The University organizes academic education and/or vocational education in several sciences, technology, and/or arts and if eligible can hold professional education" (Law of the Republic of Indonesia No 20 of 2003, 2003).

Starting from the neoclassical theory or the human relations approach. The next phase is a contemporary (modern) theory or management science stage. This contemporary stage consists of: "behavioral approach, process approach, quantitative approach, system approach, and contingency approach".

The approach used to understand management is the functions of management and cooperation. Management functions are one of the significant ways to understand management and are carried out by every manager in carrying out his duties (Montana and Charnov, 2000). Approach in understanding management through management functions and cooperation, in general, namely: management is the process of planning, organizing, commanding, coordinating, and controlling; in other words "the collective body of those who manage any enterprise or interest".

According to Luther (1995), developed a popular acronym called POSDECRB. The acronym stands for: "planning, organizing, directing, coordinating, reporting, and budgeting." Therefore, management functions according to Gulick are the POSDECRB.

Montana \& Charnov (2000), classified management functions into five sequences, with the abbreviation POSDC. The five functions are: "planning, organizing, staffing, directing, and controlling". Meanwhile, Weihrich \& Koontz (1993) mentioned managerial functions are: "planning, organizing, staffing, leading, and controlling". Williams (2000), management was defined as "getting work done through others". This is supported by Thoha's opinion which explained that management is "achieving goals through the efforts of others". So, in general, it can be interpreted as a process of activities carried out together to achieve goals.

The leadership function includes the functions of movement, guidance, evaluation, and development. The six functions mentioned above can be narrowed down to four interrelated functions, namely: planning, organizing, leading, and controlling. But Bush said three dimensions of leadership can be used as a basis for defining leadership. These three dimensions are (1) influence, (2) values, and (3) vision.

Leadership and management are very important in a university, the understanding of leadership and management is the same when it is associated with activities to influence people and other parties (Sudjana, 2006). The reason is that leadership and management both use principles and approaches to human relations. Sudjana's opinion is in line with Maurik's opinion which defines leadership, "is part of the manager's activities by which he or she influences the 
behavior of individuals or groups toward the desired result". The success of one's leadership is largely determined by the ability of human relations and personalities of these managers to achieve the intrinsic and extrinsic desires of the group they lead (Dacholfany, 2013).

To measure the quality of a tertiary institution, appropriate instruments are needed, one of which is using the Malcolm Baldridge criteria. The Malcolm Baldridge or Malcolm Baldridge Criteria for Performance Excellence are "tools for measuring an organization's performance appraisal that was originally used by the government of the United States (US) to provide Malcolm Baldridge National Quality Award to various organizations in the country "(Ghosh et al., Nd). Characteristic. Malcolm Baldridge's performance excellence is several questions about various fundamental aspects of organizational management in the context of achieving superior performance. "These questions can be grouped into seven categories, the links of which can be seen in the attached picture. The seven categories are: (a) leadership; (b) strategic planning; (c) customer focused; (d) measurement, analysis, and knowledge management; (e) workforce focused; (f) operation focused; (g) result".

\section{Methodology}

This type of research was obtained through observation of testing the development of research models. Descriptive research is data that can be analyzed with non-statistics or statistics and selected with a qualitative approach (Arikunto, 2005). Meanwhile, according to Moelong, the descriptive understanding has confirmed that this researcher can also use the available statistical data as an additional data source for his needs (Moeleong, 2007).

Evaluation of management performance in educational organizations was developed from the Malcolm Baldrige indicator which is assisted with a questionnaire, according to Garpersz there were several items or materials including (a) leader; (b) strategy planning; (c) interest in the market and customers; (d) information and analysis; (e) focuses on human resources; (f) process management; (g) business results. The results of evaluating the quality of management performance based on the Malcolm Baldrige indicator were used for the formulation of strategies for improving the quality of performance based on three models: (a) planning; (b) control; and (c) measurement (Ghosh et al, 2004).

The subjects of this research were the management and stakeholders of IAI Agus Salim Metro and STAI An Nur Lampung. Taking the subject of management with the manager's consideration is the management doer and the party who knows the most about all matters relating to management in the scope of their work.

Sampling was done by using a non-probability sampling approach, which is a sampling technique that does not provide an opportunity or opportunity for each element or member of the population to be selected as a sample. While the purposive sampling technique determines the sample based on established inclusion criteria (Arikunto, 2005).

According to Moeleong (2007), the sample size referred to the minimum sample size for survey research that is 100 respondents. The sample size of 100 people is based on the representation of the sample which depends on the level of confidence desired, the number of errors that can be tolerated, and the amount of spread (dispersion) in the population that is estimated in general. Regarding the formula (Watson et al, 2014), the sample sizes in this study could be seen in Equation (1).

$$
n=\frac{4 . Z_{1 / 2 \alpha}^{2} p(1-p)}{(\omega)^{2}}
$$

Where $\mathrm{n}$ is the sample size, $p$ is the proportion of success expected from the sample. $Q$ is the remaining proportion (1$p), Z_{1 / 2 \alpha}$ is the coefficient of confidence, $\omega=L+R$ is the number of errors that can be tolerated from the population mean on the left $(L)$ and right $(R)$ boundaries assuming $p=q$ $=50 \%, \alpha=5 \%$ and $Z_{1 / 2 \alpha}=1.96 ; L=R \$=10 \%$ and $\omega=$ $20 \%$, then based on the formula above the authors set a sample of:

$$
n=\{4 \text {. (1.96) 2. (0.5). (0.5) }\} / \text { (2.0.10) } 2=96.04 \approx 100
$$

Respondents in this study were taken as many as 200 respondents per sample group. The number of questionnaires distributed was 100 copies consisting of 50 copies distributed to management respondents and employees, 50 copies distributed to community respondents (consisting of environmental communities IAI Agus Salim Metro and An Nur STAI in Lampung Province, 50 copies were distributed to student respondents. Data analysis used a qualitative approach, namely: (a) editing, namely researching, checking and correcting the results of the answers one by one so that it can be seen following the instructions or not; (b) tabulation, which gives a score of the respondent's answer based on a predetermined measurement scale; (c) processing data following the research approach.

Approach qualitative analysis used Univariate and bivariate analysis approaches as follows: (a) Univariate Analysis, which is data that has been collected and then analyzed based on the average value of the group (item group, respondent group, and performance-expectations group) partially (univariate); (b) Analysis Bivariate, is useful to find out the gap (gap) between stakeholder expectations with the performance or performance design, then the questions in the questionnaire related to the level of importance and performance are sought for differences.

Calculating Malcolm Baldrige's score is to find the total score. By obtaining this total score, it will be easier to evaluate and compare the quality of the performance of the two universities that are being studied. How to calculate individual scores from Malcolm Baldrige's criteria is to multiply the standard total points on individual items by individual percentage scores. The percentage value obtained from the average value divided by the highest scale multiplied by one hundred percent. The equation calculation is as follows: 


\section{Category Individual (Item) Score $=$ Standard Total Point $*$ Percentage score.}

Where the percentage score $=($ average value $/$ scale $) * 100 \%$

\section{RESULTS AND DISCUSSION}

Existence Islamic tertiary institutions were recognized as having participated in contributing to the nation's intellectual development. Qualitatively PTKIS in Lampung. On a regional scale, PTKIS had contributed to the world of education in Lampung. Based on higher education institutions, religious affiliations, and organizations with different characteristics from others. There are several advantages and disadvantages in Higher Education with quality from very minimal to advanced quality spread throughout Indonesia.

In terms of human resource development planning, the two PTKIS were based on mutual needs and challenges in the future. In terms of HR recruitment at IAI Agus Salim Metro and STAI An Nur Lampung the results were: (a) at IAI Agus Salim Metro the development of the quality of human resources is implemented based on the lecturers and education personnel related to privately owned funds. If you get help from other institutions it will not reduce the ethos of human resources to continue to participate in various activities carried out by the institution and outside the institution; (b) development of human resources from various activities, the two private Islamic religious universities are relatively the same, namely, cooperation is often carried out with the Ministry of Religion and Kopertais region VII as a coordinating path for coaches, as well as the majority of their initiative for collaboration with educational development networks. In general, this development activity can be applied in the form of training and education which are relatively the same, only the intensity has a difference; (c) from the two tertiary institutions in Lampung in similar achievements and research systems, only the expectations of different work orientation. In terms of violations and mistakes in termination of employment (PHK), there is no discussion of evaluations at STAI An Nur Lampung. While at IAI Agus Salim Metro, it will result in Termination of Employment if the violations and mistakes have been violated; (d) in developing human resources, the government has participated in both institutions. The development of the quality of Lecturers and Education Personnel at STAI An Nur Lampung is supported by the Ministry of Religion and the universities themselves and is driven by the willingness of the lecturers themselves who are very prominent. Meanwhile, IAI Agus Salim Metro, the role of the government is very small in improving the quality of human resources.

In STAI An Nur Lampung the development of lecturer resources had been implemented following the data collection of skills, evaluating performance, planning, and preparing quality improvement programs. Lecturer performance was carried out planning tailored to the needs to improve lecturer performance, in addition to preparing plans by making lecturer quality improvement programs through lecturer recruitment activities, and then planning to develop them.

While the quality of Lecturers and Education Personnel at IAI Agus Salim Metro was highly considered because it is considered important in the development of Islamic religious colleges. The innovations that had been implemented are the recruitment of lecturers, the development of educational staff, at each academic community, education, training, guidance, and other activities that support the development of the quality of the lecturers and educational staff. PTKI can be developed following the expectations of the community, namely PTKI graduates must have academic and nonacademic characteristics. IAI Agus Salim Metro conducted a needs analysis and evaluation jointly between the Lecturer and the Chancellor of the Islamic Religious College to determine the estimated community needs planning, students in the future that must be applied by lecturers in meeting overall needs. Coaching activities can not only be done by PTKIS but also carried out by the foundation.

\section{CONCLUSIONS}

The results of this study were (1) the formulation of strategies for improving the quality of performance at IAI Agus Salim Metro and STAI An-Nur Lampung has not been systemic, for changes in the strategic environment have not been followed by proactive steps at the level of structure, organizational culture and management of the tertiary institution; (2) the process of implementing the strategy carried out by IAI Agus Salim Metro and STAI An-Nur Lampung has not been carried out optimally in allocating available resources, but in terms of maintaining good relations, it is highly considered, as is the relationship with stakeholders, creating trust and confidence, building competitive advantage centers and professionalism and competitiveness; (3) when viewed from its strategic management, the two PTKIS institutions are still influenced by bureaucratic culture and low adjustments to change; (4) in this point at IAI Agus Salim Metro and STAI An-Nur Lampung there is a negative gap. Wherefrom the two PTKIS is not yet maximum holds a leadership role. Improving the quality of management performance based on the strategic environment can be done by using a strategy model, this can reduce the gap and can also increase Malcolm Baldrige's scores. So that stakeholder preferences and the quality of IAI Agus Salim Metro's Management Performance are better than An Nur Lampung STAI's Management Performance Quality. This reduces gaps and can also increase Malcolm Baldrige's score. So that stakeholder preferences and the quality of IAI Agus Salim Metro's Management Performance are better than An Nur Lampung STAI's Management Performance Quality.

\section{REFERENCES}

Arikunto, Suharsimi. (2005). Manajemen Penelitian. Jakarta: PT. Adi Mahasatya.

Dacholfany, M Ihsan. (2013). Peran Kepemimpinan Perguruan Tinggi Islam dalam Pembangunan 
Peradaban Islami. 1(2).

Ghosh, Soumen, Robert B Handfield, Vijay R Kannan, and Keah Choon Tan. n.d. A Structural Model Analysis of The Malcolm Baldrige National Quality Award Framework.

Kusuma, Hendra. (2017). Pengangguran Di RI Bertambah 10.000 Jadi 7,04 Juta Orang. November 2017. https://finance.detik.com/berita-ekonomi-bisnis/d3715236/pengangguran-di-ri-bertambah-10000jadi-704-juta-orang.

Luther, Gulick. (1995). Management is a Science. 8(1).

Martono, S, and Andhi Wijayanto. (2014). Peningkatan Efektivitas Program Studi di Perguruan Tinggi Swasta melalui Kepemimpinan Adaptif Integratif. 5(1), 103-20.

Moeleong. (2007). Metode Penelitian Kualitatif. Bandung: Remaja Rosdakarya.

Montana, Patrick J, and Bruce H Charnov. (2000). Management. 3rd Edition.
R.A.De.Rozarie. (2017). Manajemen Sumber Daya Manusia. Edited by Lia. Revisi. Jawa Timur: CV R.A. De Rozarie.

Sudjana. (2006). Perlindungan Desain Tata Letak Sirkuit Terpadu Dihubungkan dengan Saya Saing Industri Elektronika Pada Era Perdagangan Bebas.

Sumardjoko, Bambang. (2010). Kontribusi Kepemimpinan dan Budaya Organisasi melalui Kompetensi Terhadap Peran Dosen dalam Penjaminan Mutu di PTS Karesidenan Surakarta. 22(1).

Undang-Undang Republik Indonesia No 20 Tahun 2003. (2003). In Jakarta.

Weihrich, Heinz, and Harold Koontz. (1993). Management A Global Perspective. 10th Edition. McGraw-Hill Collage: Subsequent edition.

Williams, Chuck. (2000). Management. Ohio: SouthWestern Collage Publishing. 